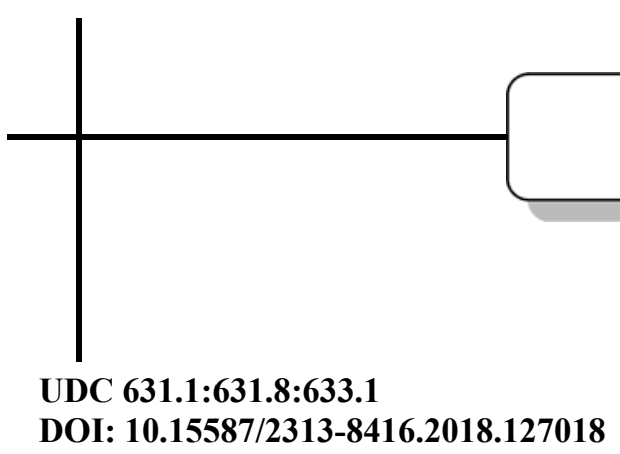

И

\title{
THE EFFECT OF NITROGEN FERTILIZER APPLICATION TIME ON THE YIELD, QUALITY AND FRACTIONAL COMPOSITION OF WINTER WHEAT GRAIN AFTER DIFFERENT PRECURSORS UNDER CONDITIONS OF THE SOUTHERN STEPPE OF UKRAINE
}

\author{
(C) A. Krivenko, O. Smetanko, S. Burykina
}

Наведені результати застосування позакореневого підживлення пшениці озимої різними нормами азотних добрив, щзо вирощуються після попередників чорного пару, гороху і ріпаку озимого та їх вплив на урожайність, якість і фракційний склад зерна. Показано,що термін весняного підживлення мало впливає на якість зерна при вирощуванні пшениці по чорному пару і гороху; по попереднику ріпак озимий підживлення слід проводити з фази масового трубкування

Ключові слова: пшениця озима, підживлення, карбамід, якість, урожай, білок, клейковина, фракиія, кореляція

\section{Introduction}

Within the structure of agroindustrial production, in the field of plant cultivation, at planting grain crops, Ukrainian economies specialize in two directions: in seed production and planting food grain. Requirements to the quality of a caryopsis are different at that. In seeds it is desirable that caryopses are big, with a great mass. In food grain, on the contrary, it must not obligatory have a high mass, but the higher protein content, the better quality, the higher price, the more profit.

Production of high-quality winter wheat grain is the most problem of agriculture of Ukraine. Complicated economic conditions of the period of establishing the statehood resulted in the abrupt worsening of quality parameters, even in the steppe zone, traditionally considered as a production zone of strong and high-value grain. During the last years food grain, produced in Ukraine mainly (67-75\%) didn't correspond to requirements of quality of the third and higher classes, when the gluten content $\geq 18,0 \%$, and protein concentration in grain is higher than $11,0 \%$. Fodder grain (sixth quality class, protein content no less than 10,5\%) stably forms a third of total volumes, delivered to bread-receiving stations. For Odessa region, I-III class grain volumes vary within $52,3 \ldots 24,5 \%$ by years [1].

At the same time the high quality of grain is a guarantee of the economic growth and indicator of a condition of a state and country in whole, because it gives a possibility to come at international markets. The internal market doesn't give to agricultural enterprises a possibility to raise profitability of the grain economy because of disparity of prices for grain realization that grew only by $42 \%$ during the last decade and cost price of the production that grew in 2,9 times during the same period at the expanse of increased prices for energy sources, fertilizers, means of plants protection. At the world market the demand for high-quality grain grows continuously and leaves supply essentially behind, so high quality grain it is an important export article that gives an important positive contribution in the state economy.

The quality of products depends on many factors, the most important among them are systems of plant nutrition, climatic conditions of their cultivation and level of soil yield. Without organizing the effective mineral nutrition and correct nitrogen feeding, winter wheat cultivation is low-profitable, doesn't cover expenditures for seeds, fertilizers, pesticides, agrotechnique and so on [2].

\section{Literary review}

Application of fertilizers taking into account biological peculiarities of a crop itself and soil-climatic conditions is a necessary component of a complex of arrangements, directed on improving the grain quality and winter wheat yield [3]. The high exactingness of this grain crop to nutrition is explained by the fact that its root system is characterized with a low ability to assimilate nutrition elements of hardly soluble soil compounds [4]. Determination of optimal doses and terms of introducing fertilizers, first of all, mitrogen, - is the main condition of their successful use, but discordances in research results are observed just in this question. Thus, the experiments demonstrated that under dry conditions the term of using nitrogen fertilizers almost didn't influence the profitability of winter wheat cultivation, and their effectiveness depended on precipitation and soil humidity [5]. Determination of a strategy of using nitrogen fertilizers on grain crops has the important value for raising their yield and production quality [6], moreover the pro- 
tein content in winter wheat grain directly depends on the application norm [7].

The experiments, conducted at the Mykolaiv SAES (southern steppe) indicate the necessity of threetime feeding: for increasing the yield by $3-4 \mathrm{c} / \mathrm{he}-\mathrm{N}_{35-45}$ in frozen-melted soil $+\mathrm{N}_{30}$ before plants outgoing in a tube, the third one with the norm $\mathrm{N}_{10-20}$ - from heading to milk ripeness - favors the increase of the protein content by $0,9-1,2 \%$ and gluten - by $3-7 \%$ [8]. In other experiments of the same zone, at the intensive technology that provided the main application of $\mathrm{N}_{30} \mathrm{P}_{60}$ and additional fertilizer $\mathrm{N}_{40}$ - renovation of spring vegetation $(\mathrm{RSV})+\mathrm{N}_{30}$ at the beginning of outgoing in a tube $+\mathrm{N}_{30}$ in the phase of milk ripeness, there was obtained the increase of productivity after precursors in average in 1,72,1 times depending on variety [9].

Under conditions of the Southern steppe at cultivating winter wheat by the precursor black fallow, grain is not lower than the second quality is obtained at introducing nitrogen in total amount up to $90 \mathrm{~kg} / \mathrm{h}$ e at feeding, the effectiveness of increased doses of $\mathrm{N}_{120-150}$ was lower [10, 11].

Scientists of the Forest-Steppe of Ukraine studied the effectiveness of the one-time fertilizing on frozenmelting soil by the norms from $\mathrm{N}_{30}$ to $\mathrm{N}_{120}$ and considered $\mathrm{N}_{90}$ as an optimal norm (precursor - pea), that provided the yield increase by $9,8 \%$ and gluten content at the level of requirements to the first quality class $(28,9 \%)$, although at $\mathrm{N}_{30}$ they obtained grain of the 2 class, but with unessential (by 1,4\%) productivity growth. The authors observed a tendency to decreasing the mass of 1000 grains and nature at feeding by the norms $\mathrm{N}_{90}$ and $\mathrm{N}_{120}$ [12].

Thus, the problem of the influence of norms and terms of feeding winter wheat by mineral nitrogen on the crop productivity and grain quality, especially in the section of soil-climatic zones remains debatable.

\section{Aim and tasks of research}

The aim of the research - is to optimize nitrogen nutrition of winter wheat under dry conditions of the Southern Steppe.

For achieving the aim, the following tasks were set:

1. To establish optimal terms and norms of adding nitrogen fertilizers at cultivating winter wheat after different precursors for conditions of the Southern Steppe.

2 . To study changes of quality parameters depending on precursor, norms and terms of adding mineral nitrogen.

\section{Material and methods of research}

Field temporary experiments were conducted during 2009-2013 in the crop rotation on the experimental field of Odessa state agricultural experimental station of NAAS of Ukraine, placed in the Western suburbs of Odessa. The territory of lands relates to the first technological group by steepness of slopes.

Natural climatic zone - Steppe; agro-soil province - DS - 1: Dry Steppe near Black Steppe. Soil of experimental plot - southern chernozem, little-humus, hardly loam on the forest rock. The power of the humus horizon $50-55 \mathrm{~cm}$. The arable layer of soil had the following agrochemical characteristic: humus content $2,95 \%$; $\mathrm{pH}$ of aqueous extract 7,8 ; content of easily-hydrolyzed nitro- gen 11,3-13,8 mg for $100 \mathrm{~g}$ of soil; movable phosphorus and accessible potassium (extract by F. Chirikov) 11,413,1 and $10,0-11,1 \mathrm{mg}$ for $100 \mathrm{~g}$ of soil, respectively.

The soil cultivation was mid-water, conventional for dry conditions of the Southern Steppe and was conducted corresponding to a precursor: black fallow [13], pea [14], winter rape [15]. The experiments were realized in three- and fourfold repeat. The area of the sowing plot is $144 \mathrm{~m}^{2}$, accounting $-80 \mathrm{~m}^{2}$. For nitrogen additional fertilizing, there was used ammoniac saltpeter (34\%) and carbamide (46\%). Winter wheat of Knop variety, which precursors were black fallow, pea and winter rape, was sown out. Sowing was realized in the term, optimal for our zone (28-30 of September). The field experiments with fertilizers were conducted by recommendations of F. A. Yudin [16].

It was harvested by a combine "Sampo-500" along plots, selecting grain samples for the analysis; the grain mass was recalculated for the standard humidity and $100 \%$ pureness.

Experimental schemes are presented at giving results.

The selection of experimental samples of grain and determination of quality parameters were realized according to standard methods: quantity and quality of gluten - SS 13586.1-68 [17], protein content - by the method of infrared spectroscopy on a device Spectran$119 \mathrm{M}$ - SS 4117:2007 [18], mass of 1000 seeds - SS 4138-2002 [19], nature of grain - SS 10840-64 [20], content of moisture by the thermo-gravimetric method SS 13586.5-93 [21]. For determining the fraction composition, grain samples were sifted on sieves with orifices $3,2 \times 20 \mathrm{~mm}, 2,6 \times 20 \mathrm{~mm}, 2,4 \times 20 \mathrm{~mm}$, which product was considered as coarse grain, and products of the sieve with orifices $2,0 \times 20 \mathrm{~mm}, 1,7 \times 20 \mathrm{~mm}$ and $1,5 \times 20 \mathrm{~mm}-$ as fine grain.

The statistical processing of the obtained results was realized by B.A. Dospekhov using the package of applied programs Excel and Statistika, by the methods of dispersion, correlation and regression analysis [22].

As to weather conditions, four of five years were favorable by humidity in spring and autumn in the active phases of growth (from March to May): there are 2009-2011 and 2013 years; 2012 year at the total amount of precipitation for vegetation as $448,1 \mathrm{~mm}$ that was $112,6 \%$ of the average index of many years was remarkable for the intense drought of the first two months of autumn $(\mathrm{ATF}=0,42)$ and unfavorable by the precipitation distribution in spring. The absence of precipitation in first two decades of May of 2012 conditioned the development of the atmospheric and then soil drought and coincided with the critical period in the development of plants of winter crops; in the third decade there were $74,4 \mathrm{~mm}$ of precipitation that could be related to optimal ones, but $93 \%$ were as a pouring rain and caused more damage than profit that was reflected on the level of yield and quality.

\section{Research results}

In the first series of the experiments there was studied the effectiveness of one-time spring fertilizing of winter wheat crops with the norm $\mathrm{N}_{60}$ in the phase from outgoing in a tube to heading. In average during three 
years (Table 1) the essential increment of yield was obtained at fertilizing at the beginning of tubing and at appearing a flag-like leaf at cultivating on black fallow (rise was 11,3 and $11,6 \%$ ); by pea - yield increment was $26,6-18,6 \%$ at adding mineral nitrogen from the beginning of tubing to appearing a flag-like leaf; by winter rape - during the tubing phase $(+14,4-13,5 \%$ to the control variant).

In separated years there was obtained the reliable increase of yield at fertilizing and in other phases of wheat plants development, but in the aforesaid periods practically stably during all years.

Table 1

Effectiveness of spring fertilizing of winter wheat crops on the background of different precursors (yield at introducing $\mathrm{N}_{60}, \mathrm{t} / \mathrm{he}$ )

\begin{tabular}{|c|c|c|c|c|c|c|}
\hline \multirow{2}{*}{ Phase of introduction } & \multicolumn{3}{|c|}{ Year } & \multirow{2}{*}{ among } & \multicolumn{2}{|c|}{ \pm to control } \\
\hline & 2009 & 2010 & 2011 & & $\mathrm{t} / \mathrm{he}$ & $\%$ \\
\hline \multicolumn{7}{|c|}{ Precursor - black fallow } \\
\hline control without adding nitrogen & 6,09 & 6,66 & 6,31 & 6,36 & 0 & 0 \\
\hline beginning of outgoing in a tube & 7,14 & 7,66 & 6,45 & 7,08 & 0,72 & 11,3 \\
\hline tubing & 6,95 & 7,39 & 6,56 & 6,97 & 0,61 & 9,6 \\
\hline appearance of a flag-like leaf & 7,34 & 7,50 & 6,45 & 7,10 & 0,74 & 11,6 \\
\hline beginning of heading & 6,47 & 6,78 & 6,38 & 6,54 & 0,18 & 2,8 \\
\hline heading & 6,04 & 6,94 & 6,22 & 6,40 & 0,04 & 0,6 \\
\hline $\operatorname{LED}_{0,95}$ & 0,18 & 0,12 & 0,16 & 0,69 & & \\
\hline \multicolumn{7}{|c|}{ Precursor - pea } \\
\hline control without adding nitrogen & 4,43 & 4,44 & 4,53 & 4,47 & 0 & 0 \\
\hline beginning of outgoing in a tube & 5,84 & 6,61 & 6,03 & 6,16 & 1,69 & 26,6 \\
\hline tubing & 5,61 & 6,13 & 5,72 & 5,82 & 1,35 & 21,2 \\
\hline appearance of a flag-like leaf & 5,69 & 5,40 & 5,86 & 5,65 & 1,18 & 18,6 \\
\hline beginning of heading & 5,07 & 5,13 & 4,25 & 4,82 & 0,35 & 5,5 \\
\hline heading & 4,57 & 5,02 & 4,08 & 4,56 & 0,09 & 1,4 \\
\hline $\operatorname{LED}_{0,95}$ & 0,12 & 0,13 & 0,12 & 0,67 & & \\
\hline \multicolumn{7}{|c|}{ Precursor - winter rape } \\
\hline control without adding nitrogen & 5,58 & 6,29 & 5,68 & 5,85 & 0 & 0 \\
\hline beginning of outgoing in a tube & 6,28 & 7,92 & 5,87 & 6,69 & 0,84 & 14,4 \\
\hline tubing & 6,14 & 7,78 & 6,01 & 6,64 & 0,79 & 13,5 \\
\hline appearance of a flag-like leaf & 5,76 & 6,78 & 5,78 & 6,11 & 0,26 & 4,4 \\
\hline beginning of heading & 5,88 & 6,84 & 6,00 & 6,24 & 0,39 & 6,7 \\
\hline heading & 5,28 & 6,84 & 5,69 & 5,94 & 0,09 & 1,5 \\
\hline $\operatorname{LED}_{0,95}$ & 0,22 & 0,27 & 0,19 & 0,62 & & \\
\hline
\end{tabular}

By protein and gluten content of such precursors as black fallow and pea, grain corresponded to the requirements of the third class of quality, despite the term of spring additional fertilizing, by winter rape - from the phase of mass tubing, at that there was observed no difference between precursors from appearing a flag-like leaf (Table 2). The main mass of grain was formed by the share more than $2,5 \mathrm{~mm}$ : in the control variant it varied within $82,8-85,5 \%$ depending on a precursor, and in the experimental ones $-75,2-87,3 \%$. The minimal content of this fraction at wheat cultivating on black fallow was observed at adding nitrogen in norm $60 \mathrm{~kg} / \mathrm{he}$ in the phase of heading beginning, by pea and winter rape - appearance of a flag-like leaf (78,6 and 69,9\%, respectively).

Table 2

Fraction share $>2,5 \mathrm{~mm}$ (product of sieves with orifices $2,6 \times 20 \mathrm{~mm}$ and 3,05 $\times 20 \mathrm{~mm}$ ) and quality of winter wheat grain depending on the term of adding mineral nitrogen $\left(\mathrm{N}_{60}\right)$ and precursor

\begin{tabular}{|l|c|c|c|c|c|c|c|c|c|}
\hline \multirow{2}{*}{ Phase of adding nitrogen } & \multicolumn{9}{|c|}{ Parameter } \\
\cline { 2 - 12 } & \multicolumn{3}{|c|}{$\begin{array}{c}\text { Fraction output }>2,5 \\
\text { mm, \% }\end{array}$} & \multicolumn{2}{c|}{$\begin{array}{c}\text { Protein content, \% for dry } \\
\text { substance }\end{array}$} & \multicolumn{3}{c|}{ Gluten content, \% } \\
\hline precursor & $\begin{array}{c}\text { black } \\
\text { fallow }\end{array}$ & pea & $\begin{array}{c}\text { winter } \\
\text { rape }\end{array}$ & $\begin{array}{c}\text { black } \\
\text { fallow }\end{array}$ & pea & winter rape & $\begin{array}{c}\text { black } \\
\text { fallow }\end{array}$ & pea & $\begin{array}{c}\text { winter } \\
\text { rape }\end{array}$ \\
\hline control & 84,4 & 85,5 & 82,8 & 11,19 & 10,61 & 9,10 & 18,5 & 17,5 & 17,0 \\
\hline $\begin{array}{l}\text { beginning of outgoing in a } \\
\text { tube }\end{array}$ & 83,8 & 83,9 & 76,7 & 11,74 & 11,65 & 10,88 & 22,0 & 20,3 & 18,4 \\
\hline mass tubing & 87,1 & 82,5 & 72,0 & 12,23 & 11,65 & 11,33 & 21,7 & 21,4 & 19,5 \\
\hline appearance of a flag-like leaf & 87,3 & 78,6 & 69,9 & 12,52 & 12,06 & 12,23 & 22,7 & 22,0 & 20,6 \\
\hline heading beginning & 75,2 & 81,1 & 76,2 & 12,15 & 12,23 & 12,20 & 21,8 & 22,0 & 21,3 \\
\hline heading & 83,1 & 83,8 & 76,8 & 12,27 & 12,09 & 12,40 & 22,7 & 22,5 & 22,8 \\
\hline
\end{tabular}


As to the mass of 1000 grains, the highest indices were in the fraction more than $3,0 \mathrm{~mm}-48,3-51,4 \mathrm{~g}$, grain fraction $2,5 \ldots 3,0 \mathrm{~mm}-38,8-41,6 \mathrm{~g}$ and $2,0 \ldots$ $2,5 \mathrm{~mm}-27,9-28,7 \mathrm{~g}$, the reliable difference by periods of fertilizing and precursors is absent within each fraction (Fig. 1).

In other series of experiments winter wheat was planted by the precursor winter rape, nitrogen fertilizers $\mathrm{N}_{60}$ were introduced from sprouting to mass growing in spring. Essential increments of yield (from 0,30 to $0,97 \mathrm{t} / \mathrm{he}$ ) were received at feeding practically in all terms, except mass growing (Table 3 ).

Protein concentration in grain at introducing nitrogen in norm $60 \mathrm{~kg} / \mathrm{he}$ in the autumn development period and in December was lower or on the limit of the third quality class (it is necessary to have 11,0 , and factually $10,57-11,10 \%$ ); at feeding from December to the mass growing - it stably was the third class $(11,56-$ $11,70 \%$ against 9,10 on the variant without fertilizers). The mass of 1000 seeds little differed by feeding terms and depended only on a grain fraction.
In the chain of crop rotation black fallow - winter wheat and pea - winter wheat both the decrease of the feeding norm to $\mathrm{N}_{90}$ and $\mathrm{N}_{120}$ and application separately in two steps are ineffective from the aspect of yield: it doesn't essentially grow comparing with one-time feeding by the norm $\mathrm{N}_{90}$, but has advantages only comparing with the control sample (sample 2). If to take into account the grain quality (Table 4,5 ), the use of $\mathrm{N}_{90}$ dose in two phases gives a possibility to get food grain of the second class, in which the protein content exceeds $12,5 \%$, and gluten $23,0 \%$, at adding $\mathrm{N}_{30}$ on sprouts and $\mathrm{N}_{60}$ in the period from mass tubing to heading at cultivating on black fallow, and by the pea precursor - the second feeding must be conducted at heading.

At increasing the norm of feeding by retail to $\mathrm{N}_{120}$ high-quality grain was obtained at all combinations of fertilizing (Fig. 2).

The correlation-regression analysis of the whole volume of obtained data allowed to reveal the influence of factors for formation of yield and quality of grain (Table 6).

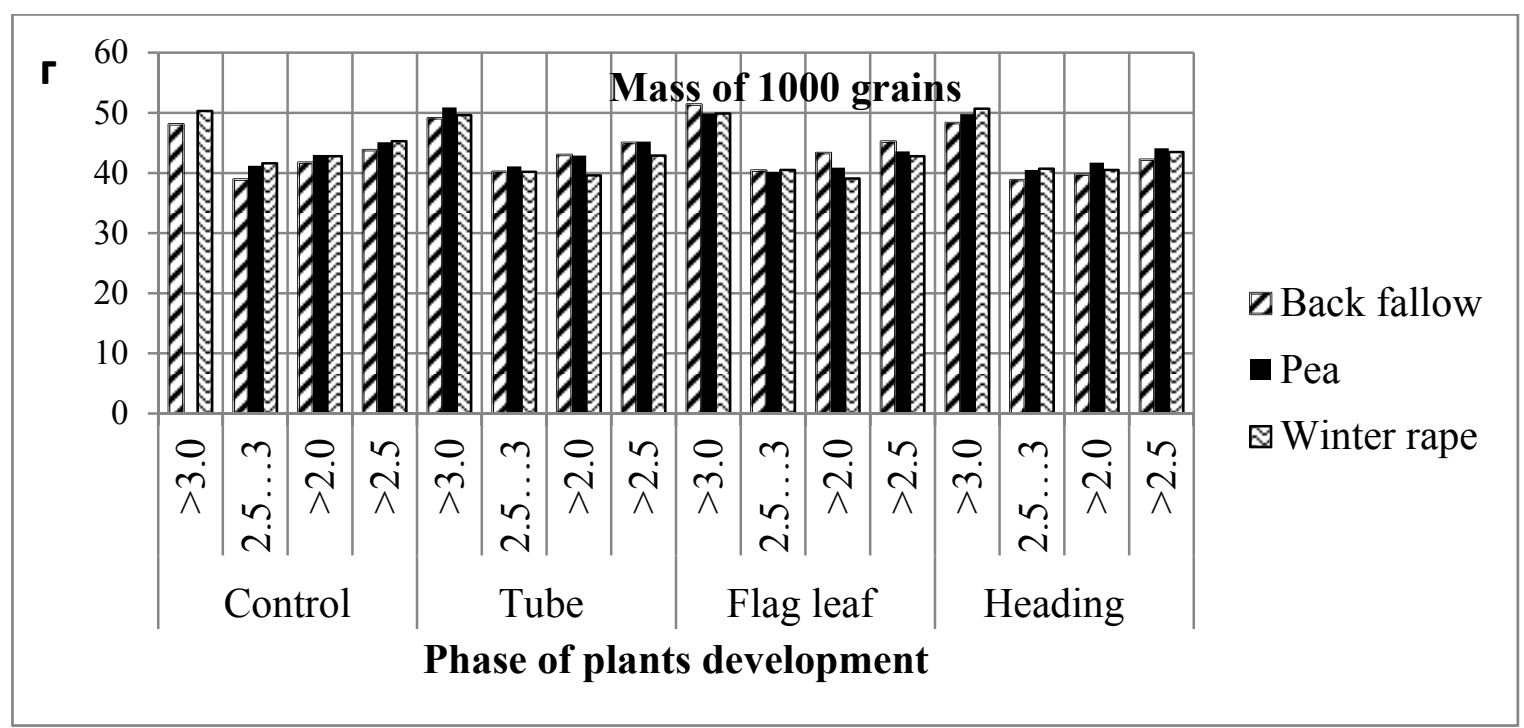

Fig. 1. Mass of 1000 seeds $\mathrm{y}$ fractions at spring feeding by the norm $\mathrm{N}_{60}$ (average for three years)

Table 3

The influence of autumn-winter and early spring feeding by mineral nitrogen on yield, fraction composition and quality of grain of winter wheat (precursor - winter rape)

\begin{tabular}{|c|c|c|c|c|c|c|c|c|c|c|c|c|c|c|}
\hline \multirow{3}{*}{$\begin{array}{l}\text { Variants of experiment } \\
\text { terms of adding the ni- } \\
\text { trogen fertilizer }\end{array}$} & \multicolumn{14}{|c|}{ Indices of studied factors } \\
\hline & \multicolumn{5}{|c|}{ Mass share of grains in harvest, } & \multicolumn{5}{|c|}{ Mass of 1000 , gramsm } & \multicolumn{2}{|c|}{$\begin{array}{c}\text { Yield of } \\
\text { grain } t / \text { he at } \\
14 \% \text { hu- } \\
\text { midity }\end{array}$} & \multirow{2}{*}{$\begin{array}{l}\text { Raw } \\
\text { pro- } \\
\text { tein }\end{array}$} & \multirow{2}{*}{$\begin{array}{l}\text { Gluten } \\
\%\end{array}$} \\
\hline & $>3 \mathrm{~mm}$ & \multirow{2}{*}{$\begin{array}{c}\begin{array}{c}2,5-3 \\
\mathrm{~mm}\end{array} \\
50,2\end{array}$} & \multirow{2}{*}{$\begin{array}{c}\begin{array}{c}2-2,5 \\
\mathrm{~mm}\end{array} \\
14,2\end{array}$} & \multirow{2}{*}{$\begin{array}{c}1,7-2 \\
\mathrm{~mm}\end{array}$} & $\begin{array}{l}<1,7 \\
\mathrm{~mm}\end{array}$ & $\begin{array}{c}>3 \\
\mathrm{~mm}\end{array}$ & $\begin{array}{c}2,5-3 \\
\mathrm{~mm}\end{array}$ & $\begin{array}{c}2-2,5 \\
\mathrm{~mm}\end{array}$ & $\begin{array}{c}>2 \\
\mathrm{~mm}\end{array}$ & $\begin{array}{c}>2,5 \mathrm{~m} \\
\mathrm{~m}\end{array}$ & \multirow{2}{*}{\begin{tabular}{|c|}
$\begin{array}{c}\text { Total- } \\
\text { ly }\end{array}$ \\
5,83 \\
\end{tabular}} & $\begin{array}{c}>2,5 \\
\mathrm{~mm} \\
\end{array}$ & & \\
\hline control $\mathrm{N}_{0}$ & 32,6 & & & & 0,8 & 50,9 & 41,6 & 28,7 & 42,8 & 45,3 & & 4,82 & 9,10 & 17,0 \\
\hline sprouts $\mathrm{N}_{60}$ & 29,7 & 48,1 & 17,9 & 3,2 & 1,1 & 48,8 & 39,4 & 27,4 & 40,1 & 43,0 & 6,13 & 4,77 & 10,57 & 18,2 \\
\hline autumn tillering $\mathrm{N}_{60}$ & 27,7 & 50,4 & 18,2 & 2,8 & 0,9 & 48,5 & 39,8 & 27,7 & 40,0 & 42,9 & 6,20 & 4,84 & 11,03 & 19,4 \\
\hline November $\mathrm{N}_{60}$ & 26,1 & 52,5 & 17,5 & 2,9 & 1,0 & 47,7 & 38,6 & 27,4 & 39,1 & 41,6 & 6,24 & 4,90 & 10,92 & 19,0 \\
\hline December $\mathrm{N}_{60}$ & 25,2 & 54,7 & 17,2 & 2,2 & 0,7 & 48,2 & 39,6 & 27,6 & 39,7 & 42,3 & 6,80 & 5,43 & 11,10 & 19,5 \\
\hline January $\mathrm{N}_{60}$ & 27,3 & 54,2 & 19,1 & 2,4 & 0,6 & 48,5 & 39,3 & 28,0 & 39,3 & 42,1 & 6,00 & 4,67 & 11,70 & 20,2 \\
\hline February $\mathrm{N}_{60}$ & 23,0 & 55,5 & 18,3 & 2,4 & 0,8 & 49,2 & 40,1 & 28,4 & 40,1 & 42,8 & 6,36 & 4,99 & 11,56 & 19,4 \\
\hline $\mathrm{RSV} \mathrm{N}_{60}$ & 22,4 & 55,1 & 19,1 & 2,5 & 0,9 & 49,4 & 39,9 & 28,3 & 39,8 & 42,7 & 6,20 & 4,80 & 11,55 & 20,2 \\
\hline mass growing $\mathrm{N}_{60}$ & 21,7 & 54,3 & 20,0 & 2,9 & 1,1 & 49,5 & 39,2 & 27,9 & 39,1 & 42,1 & 5,98 & 4,54 & 11,77 & 20,6 \\
\hline
\end{tabular}




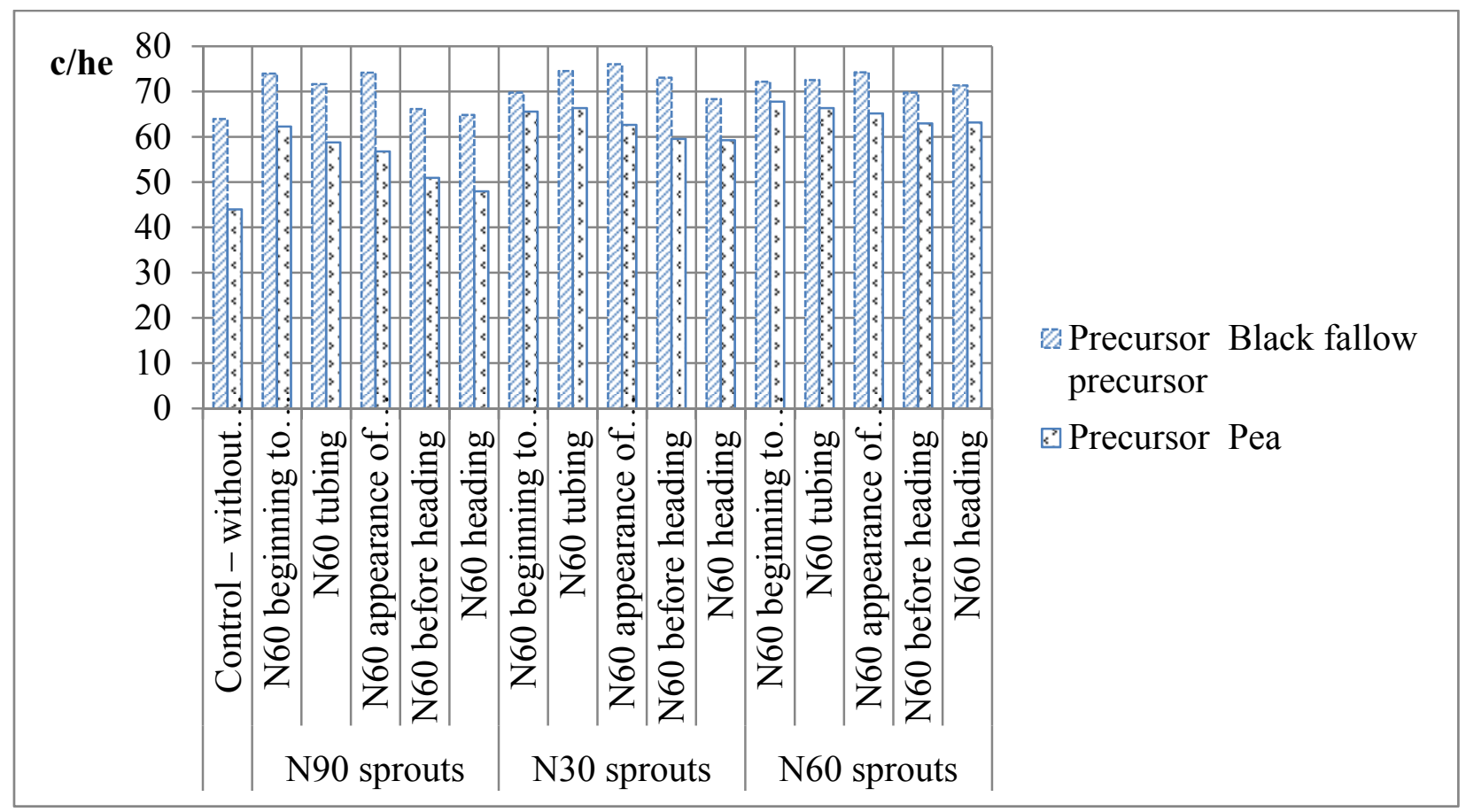

Fig. 2. Influence of terms and norms of application of nitrogen fertilizers on yield of wheat grain after black fallow and pea

Table 4

Influence of retail application of mineral nitrogen on the fraction composition and quality of winter wheat grain (precursor -black fallow)

\begin{tabular}{|c|c|c|c|c|c|c|c|c|c|c|c|c|c|}
\hline \multirow{3}{*}{$\begin{array}{l}\text { Terms and doses } \\
\text { of adding nitrogen } \\
\text { fertilizer }\end{array}$} & \multirow{2}{*}{\multicolumn{5}{|c|}{ Share of grains in yield, $\%$}} & \multirow{2}{*}{\multicolumn{5}{|c|}{$\begin{array}{c}\text { Mass of } 1000 \text { grains of separate } \\
\text { fractions, } g\end{array}$}} & \multicolumn{3}{|c|}{$\%$} \\
\hline & & & & & & & & & & & \multirow[b]{2}{*}{ protein } & \multirow[b]{2}{*}{ gluten } & \multirow{2}{*}{$\begin{array}{c}\text { Fraction } \\
\text { output } \\
>2,5 \mathrm{~mm}\end{array}$} \\
\hline & $>3 \mathrm{~mm}$ & $2,5-3 \mathrm{~mm}$ & $\begin{array}{c}2-2,5 \\
\mathrm{~mm}\end{array}$ & $\begin{array}{c}1,7-2 \\
\mathrm{~mm}\end{array}$ & $\begin{array}{l}<1,7 \\
\mathrm{~mm}\end{array}$ & $>3 \mathrm{~mm}$ & $\begin{array}{c}2,5-3 \\
\mathrm{~mm}\end{array}$ & $\begin{array}{c}2-2,5 \\
\mathrm{~mm}\end{array}$ & $>2 \mathrm{~mm}$ & $>2,5 \mathrm{~mm}$ & & & \\
\hline $\begin{array}{l}\text { Control - without } \\
\text { fertilizers }\end{array}$ & 42,1 & 42,3 & 13,0 & 1,8 & 0,8 & 48,8 & 38,9 & 28,1 & 41,7 & 43,8 & 11,19 & 19,5 & 84,4 \\
\hline $\mathrm{N}_{60}$ on sprouts & 16,5 & 58,2 & 21,5 & 2,9 & 0,9 & 46,1 & 36,9 & 27,0 & 36,3 & 38,9 & 12,27 & 21,8 & 74,7 \\
\hline $\begin{array}{l}\mathrm{N}_{30} \text { sprouts } \mathrm{N}_{60} \\
\text { beginning of out- } \\
\text { going in a tube }\end{array}$ & 19,7 & 56,4 & 20,2 & 2,8 & 0,9 & 47,6 & 38,0 & 27,3 & 37,7 & 40,5 & 12,02 & 22,7 & 76,1 \\
\hline \begin{tabular}{|l|}
$\mathrm{N}_{30^{-}}$-sprouts \\
tubing
\end{tabular} & 29,8 & 50,7 & 15,9 & 2,4 & 1,2 & 49,7 & 38,3 & 28,5 & 40,2 & 42,5 & 12,85 & 24,3 & 80,5 \\
\hline $\begin{array}{l}\mathrm{N}_{30} \text {-sprouts } \mathrm{N}_{60^{-}} \\
\text {appearance of a } \\
\text { flag-like leaf }\end{array}$ & 41,3 & 44,3 & 12,0 & 1,6 & 0,8 & 48,7 & 38,2 & 28,1 & 41,4 & 43,3 & 13,00 & 25,1 & 85,6 \\
\hline $\begin{array}{l}\mathrm{N}_{30^{-}} \text {-sprouts } \mathrm{N}_{60^{-}} \\
\text {before heading }\end{array}$ & 43,4 & 42,9 & 11,2 & 1,7 & 0,8 & 48,1 & 39,3 & 27,7 & 41,9 & 43,7 & 13,20 & 25,1 & 86,3 \\
\hline $\begin{array}{|ll|}\mathrm{N}_{30^{-}} \text {-sprouts } & \mathrm{N}_{60^{-}} \\
\text {heading } & \\
\end{array}$ & 20,5 & 54,7 & 20,6 & 3,1 & 1,1 & 47,1 & 38,0 & 27,6 & 37,7 & 40,5 & 12,90 & 24,2 & 75,2 \\
\hline $\begin{array}{l}\mathrm{N}_{60} \text {-sprouts } \\
\text { beginning of out- } \\
\text { going in a tube }\end{array}$ & 19,4 & 57,8 & 19,4 & 2,6 & 0,8 & 46,5 & 36,7 & 27,2 & 36,8 & 39,2 & 14,10 & 26,0 & 77,2 \\
\hline \begin{tabular}{|l|}
$\mathrm{N}_{60^{-}}$-sprouts \\
tubing
\end{tabular} & 25,6 & 53,6 & 17,3 & 2,5 & 1,0 & 46,9 & 37,8 & 27,5 & 38,4 & 40,7 & 14,80 & 24,6 & 79,2 \\
\hline \begin{tabular}{ll|}
$\mathrm{N}_{60^{-}}$-sprouts & $\mathrm{N}_{60^{-}}$ \\
appearing of & $\mathrm{a}$ \\
flag-like leaf & \\
\end{tabular} & 38,3 & 45,4 & 13,4 & 1,9 & 1,0 & 48,0 & 38,1 & 28,1 & 40,6 & 42,6 & 13,09 & 24,2 & 83,7 \\
\hline $\begin{array}{l}\mathrm{N}_{60^{-}} \text {-sprouts } \quad \mathrm{N}_{60^{-}} \\
\text {before heading }\end{array}$ & 48,1 & 39,1 & 10,4 & 1,6 & 0,8 & 48,2 & 38,4 & 27,9 & 42,1 & 43,8 & 12,63 & 23,6 & 87,2 \\
\hline \begin{tabular}{|l|}
$\mathrm{N}_{60^{-}}$-sprouts \\
heading
\end{tabular} & 46,9 & 39,2 & 11,2 & 1,8 & 0,9 & 49,2 & 39,5 & 28,0 & 42,9 & 44,8 & 12,75 & 23,0 & 86,1 \\
\hline
\end{tabular}


Table 5

Influence of retail application of mineral nitrogen on the fraction composition and quality of winter wheat grain (precursor - pea)

\begin{tabular}{|c|c|c|c|c|c|c|c|c|c|c|c|c|}
\hline \multirow{3}{*}{$\begin{array}{l}\text { Terms and doses of adding ni- } \\
\text { trogen fertilizer }\end{array}$} & \multirow{2}{*}{\multicolumn{5}{|c|}{ Fraction of grains in yield, $\%$}} & \multirow{2}{*}{\multicolumn{5}{|c|}{$\begin{array}{l}\text { Mass of } 1000 \text { grains of separate } \\
\text { fractions, } g\end{array}$}} & \multicolumn{2}{|c|}{$\%$} \\
\hline & & & & & & & & & & & \multirow[b]{2}{*}{$\begin{array}{l}\text { pro- } \\
\text { tein }\end{array}$} & \multirow[b]{2}{*}{$\begin{array}{l}\text { glu- } \\
\text { ten }\end{array}$} \\
\hline & $\begin{array}{c}>3 \\
\mathrm{~mm}\end{array}$ & $\begin{array}{c}2,5-3,0 \\
\mathrm{~mm}\end{array}$ & $\begin{array}{c}2-2,5 \\
\mathrm{~mm}\end{array}$ & $\begin{array}{c}1,7-2 \\
\mathrm{~mm}\end{array}$ & $\begin{array}{l}<1,7 \\
\mathrm{~mm}\end{array}$ & $\begin{array}{l}>3 \\
\mathrm{~mm}\end{array}$ & $\begin{array}{c}2,5-3 \\
\mathrm{~mm}\end{array}$ & $\begin{array}{c}\begin{array}{c}2-2,5 \\
\mathrm{~mm}\end{array} \\
\end{array}$ & $\begin{array}{c}>2 \\
\mathrm{~mm}\end{array}$ & $\begin{array}{l}>2,5 \\
\mathrm{~mm}\end{array}$ & & \\
\hline Control - withor & 38,1 & 47,4 & 11,9 & 1,9 & 0,7 & 49,9 & 41,2 & 28,3 & 43,0 & 45,1 & 10,61 & 19,1 \\
\hline $\mathrm{N}_{60}$ on & 30,9 & 52,3 & 14,0 & 2,0 & 0,8 & 48,4 & 39,6 & 27,5 & 40,6 & 42,9 & 11,30 & 20,5 \\
\hline $\begin{array}{l}\mathrm{N}_{30} \text { sprouts } \mathrm{N}_{60} \text { beginning of } \\
\text { outgoing in a tube }\end{array}$ & 3 & 4 & 10,8 & 2,0 & 0,6 & 48,0 & 39,8 & 27,5 & 41,8 & 43,5 & 11,60 & 20,7 \\
\hline $\mathrm{N}_{30}$-sprouts $\mathrm{N}_{60}$-tubing & 32,3 & ,0 &,+ 0 & 2,0 & 0,7 & 47,8 & 40,1 & 28,1 & 40,9 & 43,1 & 12,10 & 21,6 \\
\hline $\begin{array}{l}\mathrm{N}_{30} \text {-sprouts } \mathrm{N}_{60} \text {-appearance of } \\
\text { a flag-like leaf }\end{array}$ & 22,8 & 53,0 & 19,2 & 3,5 & 1,4 & 47,8 & 39,5 & 27,5 & 39,1 & 42,0 & 12,25 & 22,2 \\
\hline $\begin{array}{l}\mathrm{N}_{30} \text {-sprouts } \mathrm{N}_{60} \text {-before head- } \\
\text { ing }\end{array}$ & 22,9 & J, & 10,0 & 2,9 & 1,0 & 48,5 & 39,8 & 27,7 & 38,6 & 42,3 & 12,54 & 24,4 \\
\hline $\mathrm{N}_{30}$-sprouts $\mathrm{N}_{60}$-heading & 28,4 & 51,8 & 16,4 & 2,5 & 0,9 & 49,2 & 40,1 & 27,7 & 40,7 & 43,3 & 13,02 & 24,2 \\
\hline $\begin{array}{l}\mathrm{N}_{60} \text {-sprouts } \mathrm{N}_{60} \text {-beginning of } \\
\text { outgoing in a tube }\end{array}$ & 26,4 & 5 & 1 & 2,4 & 0,9 & 47,9 & 39,2 & 27,2 & 39,5 & 42,1 & 12,51 & 23,0 \\
\hline $\mathrm{N}_{60}$-sprouts $\mathrm{N}_{60}$-tubing & 19,9 & 55,9 & 20,2 & 3,0 & 1,0 & 47,8 & 38,9 & 27,2 & 38,3 & 41,2 & 13,51 & 24,3 \\
\hline $\begin{array}{l}\mathrm{N}_{60} \text {-sprouts } \mathrm{N}_{60} \text {-appearing of } \\
\text { flag-like leaf }\end{array}$ & 15,5 & 57,8 & 22,2 & 3,4 & 1,1 & 48,4 & 39,2 & 27,4 & 38,0 & 41,2 & 12,10 & 24,5 \\
\hline $\begin{array}{l}\mathrm{N}_{60} \text {-sprouts } \mathrm{N}_{60} \text {-before head- } \\
\text { ing }\end{array}$ & 17,8 & 5 & 2 & 3,0 & 1,0 & 48,4 & 39,3 & 28,2 & 38,5 & 41,5 & 12,85 & 23,7 \\
\hline $\mathrm{N}_{60}$-sprouts $\mathrm{N}_{60}$-heading & 24,6 & 53,0 & 18,0 & 3,2 & 1,2 & 48,9 & 39,8 & 27,1 & 39,7 & 42,7 & 12,81 & 23,6 \\
\hline
\end{tabular}

Table 6

Pair coefficients of correlation and determination

\begin{tabular}{|c|c|c|c|c|c|c|c|c|c|c|c|}
\hline \multirow{3}{*}{ Precursor } & \multicolumn{3}{|c|}{$\begin{array}{l}\text { Norm of application of min- } \\
\text { eral nitrogen }\end{array}$} & \multirow{2}{*}{\multicolumn{2}{|c|}{$\begin{array}{c}\text { Share of frac- } \\
\text { tions of fine } \\
\text { grain - protein } \\
\text { content } \\
\end{array}$}} & \multirow{2}{*}{\multicolumn{2}{|c|}{$\begin{array}{l}\text { Share of fractions } \\
\text { of coarse grain - } \\
\text { protein content }\end{array}$}} & \multirow{2}{*}{\multicolumn{2}{|c|}{$\begin{array}{c}\text { Share of fractions } \\
\text { of coarse grain - } \\
\text { gluten content }\end{array}$}} & \multirow{2}{*}{\multicolumn{2}{|c|}{ Protein-gluten }} \\
\hline & \multirow{2}{*}{$\frac{\text { yield }}{\mathrm{r}}$} & \multicolumn{2}{|c|}{ Content } & & & & & & & & \\
\hline & & $\mathrm{r}$ & $\mathrm{r}$ & $\mathrm{r}$ & $\mathrm{r}^{2}$ & $\mathrm{r}$ & $\mathrm{r}^{2}$ & $\mathrm{r}$ & $\mathrm{r}^{2}$ & $\mathrm{r}$ & $\mathrm{r}^{2}$ \\
\hline $\begin{array}{l}\text { Black } \\
\text { fallow }\end{array}$ & 0,26 & 0,92 & 0,98 & 0,01 & 0 & $-0,35$ & 0,12 & $-0,04$ & 0,002 & 0,73 & 0,53 \\
\hline pea & 0,52 & 0,64 & 0,50 & 0,52 & 0,25 & $-0,63$ & 0,40 & $-0,57$ & 0,37 & 0,95 & 0,90 \\
\hline $\begin{array}{l}\text { winter } \\
\text { rape }\end{array}$ & 0,80 & 0,57 & 0,50 & 0,73 & 0,53 & ),69 & 0,48 & $-0,42$ & 0,18 & 0,92 & 0,85 \\
\hline
\end{tabular}

It is known, that pair correlation coefficients testify to the close connection between two variables: at module values more than 0,7 - strong connection, at $r \geq 0,5$ and $<0,7$ - middle and at $r$ less than 0,5 - weak. According to the correlation-regression analysis, the influence of the norm of application of mineral nitrogen grows with decreasing the precursor's quality: if the yield level for black fallow was determined by the norm of nitrogen feeding by $6,8 \%$, for pea - by $27,0 \%$, and by winter rape - by $64 \%$; at that pair coefficients of correlation between the norm of nitrogen fertilizers in feeding and protein and gluten content for black fallow are the highest $(0,92-0,98)$, that testify to the high degree of connection, and for pea and winter rape - middle degree $(\mathrm{r}=0,64$ and 0,50 and 0,57 and 0,50$)$.

At cultivating winter wheat on black fallow, there was revealed the weak reverse connection between the share of coarse grain fraction and protein content $(\mathrm{r}=-0,35)$; at cultivating on pea or winter rape, the influence direction is the same (increase of the coarse fraction share results in decreasing the protein concentration), but the influence degree is middle. The influence of the big size of grain on the gluten content repeats the previous scenario at the comparatively less closeness of connection. The share of fine grain and protein content are in the direct connection of the middle degree: $r=0,52$ at cultivating on the precursor pea and $\mathrm{r}=0,73-$ on winter rape).

Summarizing the obtained data, we can say that the terms and ways (one-time or retail) of nitrogen application in feeding must be chosen taking into account the production direction. For example, at cultivating winter wheat for seeds it is more rational to fertilize additionally by nitrogen fertilizers $\mathrm{N}_{60}$ in the phase of appearance of a flag-like leaf. Such feeding provides the high yield of grain as $7,10 \mathrm{t} / \mathrm{ha}$ that is by $0,74 \mathrm{t} / \mathrm{he}$ higher than in the control, and almost at the same level with the yield at using $\mathrm{N}_{90}$ and $\mathrm{N}_{120}$ fertilizers as feeding at retail application - on sprouts and at growing a flag-like leaf $(7,46-7,34 \mathrm{t} / \mathrm{he})$. At the same time the highest output of grain is left on a sieve with orifices $3,0 \mathrm{~mm}$ and high percent of the output of the seed fraction with the 
diameter more than $2,5 \mathrm{~mm}(87,7 \%)$. At cultivating food grain, it is reasonable to include feeding by the scheme $\mathrm{N}_{60}$ on wheat sprouts from autumn and $\mathrm{N}_{60}$ during the tubing phase in the technology. At that the yield forms at the level 6,73-6,75 t/he, grain has a less size and mass, but the gluten and protein contents are high 14,1-14,8\% and $26,0-24,6 \%$, respectively, that relates to the second class by gluten (gluten in grain of the first class must not be lower than $28,0 \%$ ), and protein concentration corresponds to requirements of 1-st class (not lower than $14,0 \%$ ); such grain may be used for improving quality parameters of other grain fractions and as a raw material for macaroni products.

At planting winter wheat after the precursor pea for seeds it is most rational to use the following system of additional fertilizing: to apply nitrogen in the norm $\mathrm{N}_{90}$ by retail $\left(\mathrm{N}_{30}\right.$ on sprouts before the tillering phase, and $\mathrm{N}_{60}$ in spring at the beginning of outgoing in a tube). Such variant of feeding provides the high yield of grain $6,46 \mathrm{t} / \mathrm{he}$ that is by $1,99 \mathrm{t} / \mathrm{he}(44,5 \%)$ higher than the control, the share of seeds with the diameter more than $2,5 \mathrm{~mm}$ is $86,5 \%$ and has the mass of 1000 seeds as 43,5 grams. For obtaining high-quality food grain, it is necessary to conduct the nitrogen feeding in two times, namely $\mathrm{N}_{60}$ in autumn on sprouts and $\mathrm{N}_{60}$ at tubing. At that the yield of $6,82 \mathrm{t} / \mathrm{he}$ is a bit lower than at application at the beginning of outgoing of plants of winter wheat in a tube, grain is fine, but has the most protein content $(13,1 \%)$ and gluten one $24,3 \%$ comparing with other variants that corresponds to the quality parameter of the third class.

After the precursor winter rape the highest yield of seeds $6,80 \mathrm{t} / \mathrm{he}$ and the share of a seed fraction with the diameter more than $2,5 \mathrm{~mm}-5,43 \mathrm{t} /$ he was provided by adding $\mathrm{N}_{60}$ in December, before finishing the spring vegetation. The protein content in seeds is not very high $11,1 \%$, gluten $-19,5 \%$.

The optimal term of application and the norm of the nitrogen fertilizer must be considered as $\mathrm{N}_{60}$ in the phase of wheat tubing. At that the yield is at the level of $6,64 \mathrm{t} / \mathrm{he}$, protein content $-11,33 \%$, gluten $-19,5 \%$. According to SSU 3768:2010, such grain relates to the third food class. Grain with the higher protein content $(12,23-12,40 \%)$ and gluten content (20,6-22,8 \%) forms at feeding by the norm $\mathrm{N}_{60}$ in the period from appearing a flag-like leaf to heading phase, but at that the tendency to decreasing the yield by $0,40-0,70 \mathrm{t} / \mathrm{he}$ comparing with $\mathrm{N}_{60}$ in the tubing phase is observed.
At that, it must be taken into account, that these results are obtained at cultivating winter wheat at plots, where the arable soil layer had the middle degree of provision with accessible nutrition elements.

\section{Conclusions}

Thus, based on the conducted studies on southern, little-humus, hard-loamy soil with the middle level of provision with accessible nutrition elements it was established:

1. At cultivating winter wheat for seeds and food grain, the optimal terms and norms of application of nitrogen fertilizers in feeding are different: on the precursor black fallow at cultivating fallow wheat for seeds it is more rational to conduct the feeding by nitrogen fertilizers $\mathrm{N}_{60}$ in the phase of appearing a flag-like leaf; for obtaining high-quality food grain it is rational to apply $\mathrm{N}_{60}$ on wheat sprouts from autumn $+\mathrm{N}_{60}$ during the tubing phase.

At cultivating winter wheat after the precursor pea for seeds - the nitrogen fertilizer must be applied in the norm $\mathrm{N}_{90}$ by retail $\left(\mathrm{N}_{30}\right.$ on sprouts before beginning the tillering phase, and $\mathrm{N}_{60}$ in spring at the stage of outgoing in a tube); for obtaining high-quality food grain it is necessary to conduct the nitrogen fertilizing also in two terms, namely $\mathrm{N}_{60}$ in autumn on sprouts and $\mathrm{N}_{60}$ at tubing;

After the precursor winter rape, the most yield of seeds $6,80 \mathrm{t} / \mathrm{he}$ and share of seeds fraction with the diameter more than $2,5 \mathrm{~mm}-5,43 \mathrm{t} /$ he is provided by introducing $\mathrm{N}_{60}$ in December, before ending the autumn vegetation. The optimal term for applying the nitrogen fertilizer for obtaining food grain with the quality parameters of the third class $-\mathrm{N}_{60}$ is in the wheat tubing phase. Delay of the feeding term results in decreasing the yield on the background of the quality increase, but within requirements to the third class.

2. The term of the spring feeding little influences the grain quality at cultivating wheat on black fallow and pea: by the protein and gluten contents it corresponds to requirements of the third quality class; for obtaining grain of the high class with the protein content no less than $11-12 \%$ and gluten $18-23 \%$, the feeding of winter wheat crops on the precursor winter rape by the nitrogen fertilizer must be conducted from the mass tubing phase. At later one, the high quality of grain is not determined by the precursor, but depends only on the norm of the nitrogen fertilizer.

\section{References}

1. Ozyma pshenytsia v boharnykh umovakh Prychornomorskoho stepu / Druziak V. H. et al. // Zerno i khlib. 2013. Issue 2. P. 62-65.

2. Pshenytsia na pivdni / Bilyk D. P. et al.; ed. by Vinnytskyi S. P. Odessa: Maiak, 1964. 157 p.

3. Naukove zabezpechennia staloho rozvytku silskoho hospodarstva v Lisostepu Ukrainy / ed. by Melnychuk D. O. et. al. Kyiv: Alefa, 2003. 886 p.

4. Marchuk I. U., Makarenko V. M., Rozstalnyi V. E. Vesennee pitanie ozimoy pshenitsy // Nastoyashhiy khozyain. 2004. Issue 2. P. 19-21.

5. Bushong J. T., Arnall D. B., Raun W. R. Effect of Preplant Irrigation, Nitrogen Fertilizer Application Timing, and Phosphorus and Potassium Fertilization on Winter Wheat Grain Yield and Water Use Efficiency // International Journal of Agronomy. 2014. Vol. 2014. P. 1-12. doi: 10.1155/2014/312416

6. Jolans J. I. Fertilizer in UK farming // University of Reading. Contre for Agricultural Strategy. 1985. № 9. 215 p.

7. Znao J.-Y., Yu Z. W. Effect of Nitrogen Fertilizer Rate on Photosyntetic Rate and Photochemical Efficiency of Flag Leaf, Grain Yield and Protein Content of Winter Wheat // Journal of Triticeae Crops. 2006. Issue 5. P. 92-96.

8. Kompleks vesenne-polevykh rabot v khozyaystvakh Nikolaevskoy oblasti v 2017 godu: nauch.-pr. rek. Nikolaev: Nikolaevskaya GSKHOS IOZ NAAN, 2017. 22 p. 
9. Bordyuzha, N. P. Optymizatsiia udobrennia pshenytsi ozymoi dlia polipshennia biokhimichnykh pokaznykiv yakosti zerna: proceedings // Modern directions of theoretical and applied researches. URL: http://www.sworld.education/conference/yearconference-sw/the-content-of-conferences/archives-of-individual-conferences/march-2016 (Last accessed: 18.02.2018)

10. Cherenkov A. V., Hyrka A. D. Shliakhy pidvyshchennia zernovoi produktyvnosti ozymoi pshenytsi v umovakh pivnichnoi pidzony Stepu Ukrainy // Biuleten Instytutu zernovoho hospodarstva UAAN. 2005. Issue 23-24. P. 36-39.

11. Hyrka A. D. Formuvannia vrozhainosti ta yakosti zerna ozymoi pshenytsi zalezhno vid pidzhyvlennia i zasobiv zakhystu v umovakh pivnichnoho Stepu Ukrainy: Abstract's PhD thesis. Dnipropetrovsk, 2007. 19 p.

12. Liashenko V. V., Solianyk O. M. Urozhainist i yakist zerna ozymoi pshenytsi zalezhno vid rikhnykh doz azotnoho pidzhyvlennia. 2007. URL: http://www.rusnauka.com/19_NNM_2007/Agricole/23412.doc.htm (Last accessed: 18.02.2018)

13. Tekhnologiya podgotovki chernogo para v Stepnoy zone USSR: metod. rek. Dnepropetrovsk: Vsesoyuznyy nauchnoissledovatel'skiy institut kukuruzy, 1988. $19 \mathrm{p}$.

14. Razvadovskyi A. M. Intensyvna tekhnolohiia vyroshchuvannia horokhu. Kyiv: Urozhai, 1988. 92 p.

15. Rekomendatsii z vyroshchuvannia ozymoho ripaku. Ivano-Frankivsk: Ivano-frankivskyi instytut APV UAAN, 2006. 21 p.

16. Opytnoe delo v polevodstve / ed. by Nikitenko G. F. Moscow: Rossel'khozizdat, 1982. 190 p.

17. GOST 13586.1-68. Zerno. Metody opredeleniya kolichestva i kachestva kleykoviny v pshenitse (s izmeneniyami 1,2). Chinniy vid 1991-09-01. Zmini: 1971-07-01; 1998-09-02. Moscow: Standartinform, 2009. 6 p.

18. DSTU 4117:2007. Zerno ta produkty yoho pererobky. Vyznachennia pokaznykiv yakosti metodom infrachervonoi spektroskopii. Chynnyi vid 2007-08-01. Kyiv: Derzhspozhyvstandart Ukrainy, 2007. 7 p.

19. GOST 10842-89 (ISO 520-77). Zerno zernovykh i bobovykh kul'tur i semyan maslichnykh kul'tur. Metod opredeleniya massy 1000 zeren ili 1000 semyan. Chinniy vid 1995-06-01. Moscow: Standartinform, 2009. 4 p.

20. GOST 10840-64. Zerno. Metody opredeleniya natury. Chinniy vid 1988-07-01. Moscow: Standartinform, 2009. 4 p.

21. GOST 13586.5-93. Zerno. Metod opredeleniya vlazhnosti. Chinniy vid 1993-06-01. Mezhgosudarstvennyy sonet po standartizatsii, metrologi i sertifikatsii. Minsk, $1993.8 \mathrm{p}$.

22. Dospekhov B. A. Planirovanie polevogo opyta i statisticheskaya obrabotka ego dannyakh. Moscow: Kolos, 1971. 207 p.

Рекомендовано до публікащії д-р с.-г. наук Січкар В. I. Дата надходження рукопису 28.02.2018

Anna Krivenko, PhD, Associate Professor, Odessa State Agricultural Experimental Station Of The National Academy Of Agrarian Sciences Of Ukraine, Maiatska doroha str., 24, smt. Khlebodarskoe, Belyaevsky district, Odessa region, Ukraine, 67667

E-mail: kryvenko35@ukr.net

Alexander Smetanko, PhD, Head of Department, Scientific And Technological Department Of Agrochemistry, Soil Science And Organic Production, Odessa State Agricultural Experimental Station Of The National Academy Of Agrarian Sciences Of Ukraine, Maiatska doroha str., 24, smt. Khlebodarskoe, Belyaevsky district, Odessa region, Ukraine, 67667

E-mail: smetanko84@ukr.net

Svetlana Burykina, PhD, Leading Researcher, Scientific And Technological Department Of Agrochemistry, Soil Science And Organic Production, Odessa State Agricultural Experimental Station Of The National Academy Of Agrarian Sciences Of Ukraine, Maiatska doroha str., 24, smt. Khlebodarskoe, Belyaevsky district, Odessa region, Ukraine, 67667

E-mail: burykina@ukr.net 